\title{
Critical perspective of English teaching and learning in Turkey
}

\author{
Ömer Gökhan Ulum ${ }^{1}$, Kutay Uzun ${ }^{2}$ \\ ${ }^{1}$ Department of English Language Teaching, Mersin University, Turkey \\ ${ }^{2}$ Department of English Language Teaching, Trakya University, Turkey
}

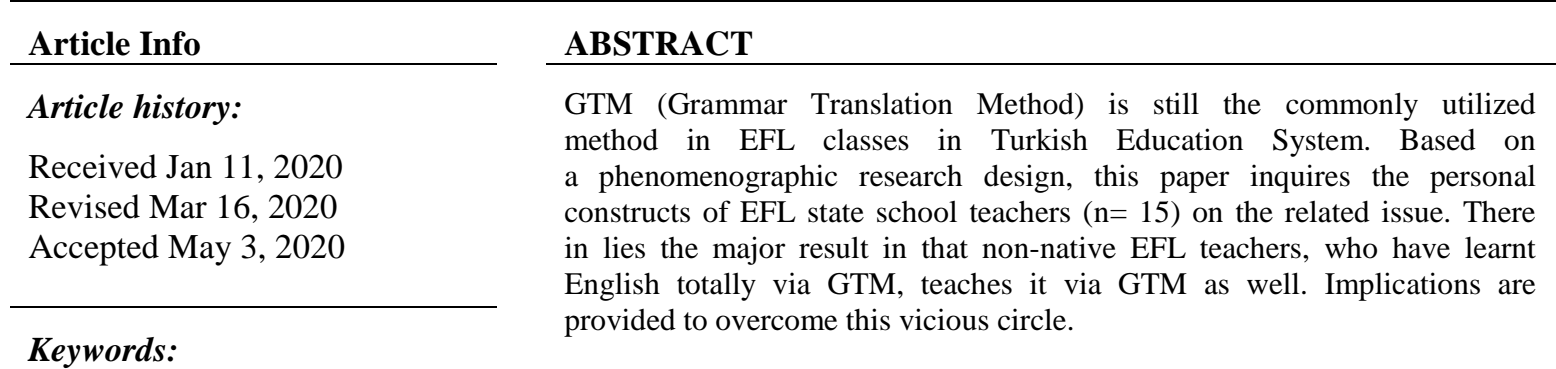

English as a foreign language

Grammar translation method

Turkish EFL learners

This is an open access article under the CC BY-SA license.

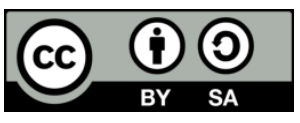

\section{Corresponding Author:}

Ömer Gökhan Ulum,

Department of English Language Teaching,

Education Faculty,

Mersin University,

Ciftlikkoy Campus, Mersin, Turkey.

Email: omergokhanulum@gmail.com

\section{INTRODUCTION}

Learning a foreign language develops the memory of the children, as well as enriching their imagination [1, 2]. Teaching a foreign language involves practicing four language skills and training learners accordingly. Communicative competence is generally emphasized in foreign language instruction. This term contains proficiency of four language skills (reading, writing, listening, and speaking) [3], besides their involvement in the process of language teaching $[4,5]$.

The merit of learning a foreign language has been stressed for a long while and a large spectrum of related programs and researches have been represented [6]. Accordingly, compulsory education was enhanced to twelve years in Turkey in 2012 [7], in which education involved three steps. The initial step involves primary school education for four years [8]. The next step refers to secondary school education lasting for four years as well. Further, the last step involves high school level for four years [9]. Improvements and transformations in EFL curriculum are composed of improving the main language skills and the fundamentals of the Common European Framework of Reference for Languages which refers to learning, teaching, and assessing a foreign language [10]. The Ministry of Turkish National Education declared that PISA scores suggest that Turkish students are not equipped with the required knowledge and skills for international standards [11]. The situation seems to be the same $[12,13]$.

Turkish people frequently state that they can comprehend English but they cannot speak it [14-16]. Thus, inability to speak English has turned to be a syndrome in Turkish society [17-19]. Since it has been found out that education is a must for the long-term economic development and for diminishing both 
economic and social disadvantages, inequality in education and its consequences have appeared to be some of the main issues in several countries [20-23]. Accordingly, Turkey may be given as a good example to evaluate the relations between regional inequalities, class, and education in which education is firmly a classassociated matter [24].

The view that though the learners can attain high levels of competency in reading, writing, and listening, they are not able to speak English is so common in Turkey [25]. This is a tragic concept since the students own obligatory and optional English lessons during their obligatory school education [26]. This problem has been previously attributed to learner autonomy, learning anxiety, flaws in teacher training and empowerment, as well as inadequacy of the required technology and materials in foreign language classes [27]. Considering all these aspects, this study inquires the issue of EFL proficiency within Turkish context.

\section{RESEARCH METHOD}

This study is descriptive and qualitative in nature. A phenomenographic method [28, 29] was adopted by including open-ended interview questions formed by the researcher. For the semi-structured interview questions, inter-coder reliability was conducted. For the coding reliability of the interview, Kappa Coefficient for Inter-coder Reliability was calculated and it was found that the coding process was highly reliable $(\mathrm{K}=.889, \mathrm{p}<.001)$. Phenomenographic research design aims to understand how individuals experience and think about an event or phenomena within the framework of interpretative paradigm [30, 31]. The participants were given information about the nature of the study. The data were examined by using inductive content analysis. The number of the participants was composed of 15 public school English teachers. Their average age was 30. Each participant had at least a 7-year experience in language teaching. All of the participants majored in English language teaching. None of them had international experience in speaking English in inner circle countries composed of the United Kingdom, the United States of America, Canada, New Zealand or Australia.

\section{RESULTS AND DISCUSSION}

All of the participants $(n=15)$ noted that it was hard to teach the learners through communicative approach because of the exams conducted in Turkey [32]. Therefore, they had to teach via grammar translation method emphasizing only receptive skills composed of mainly reading and grammar [33]. Another problem was that the number of the students in the classes was high $(n=15)$. In addition, English language teaching departments focused more on grammar translation [34] method even in other modern approaches were introduced to the teachers $(\mathrm{N}=14)$. The participants' pre-service experiences were also grammar-translation based $(n=15)$. Therefore, they noted that they were unable to use communicative approach in the classroom settings $(n=15)$. Besides, communicative and pragmatic competence of the participants was insufficient [35].

The participants $(n=10)$ emphasized that they had never been abroad and encountered any native speaker in their lifetime, which posed a serious problem for them. Another problem was that strategic competence [36] was not taught to the participants $(n=10)$. They noted that they never received such training during their university education. Therefore, they said that they were unable to develop their productive, communicative, strategic and pragmatic competence and skills [37] $(n=10)$. They also articulated that the learners came to the classroom setting to pass the exam in Turkey $(n=15)$. They had low motivation to produce the foreign language because the exam anxiety was very dominant and preceded other concerns [38]. Therefore, around half of the participants noted that it was hard to teach them productive skills, which caused the participants to focus on only grammar-translation method $(n=8)$.

The policy of the schools and ministry of education in Turkey also led the participants $(n=15)$ to use this traditional method and approach. Thus, they tended to avoid utilizing modern approaches that have been repeatedly emphasized in the related literature because the main language policy in Turkey was largely exam-based. The participants $(n=7)$ also said that English language departments were also unable to bring concrete solutions to this problem at either macro or micro level because participatory and critical approaches were not emphasized and reinforced. Therefore, the policies can be said to affect the learners and teachers negatively and adversely. In addition, language policies regarding English language teaching and learning were not addressed between 2005 and 2013 in Turkey. English language departments were also not involved in the formation of democratic policies. Thus, the participants said that they felt helpless about using new and modern language teaching and learning methods and approaches [39] $(n=11)$

Another dimension was that the motivation of the participants $(n=10)$ was rather low because of the high number of the students in the classroom settings. They remarked $(n=10)$ that it was formidable and 
impractical to urge the learners to develop productive skills. The time allocated to English language in public schools was totally inadequate. The participants $(n=6)$ also said that European countries were successful in language teaching because their syllabus and curriculum were production-based and that Turkey should prepare new syllabi and curricula that emphasize oral skills [40].

The participants $(n=13)$ recommended that English teachers in Turkey should visit inner circle countries to observe and thus gain experiences and new perspectives about English language teaching. They $(n=13)$ also suggested that lack of experience in speaking English with native speakers and even advanced non-native speakers caused them not to know how to use communicative approach in classroom settings because they lacked this international experience. What they $(n=13)$ expect is that ministry of education in Turkey and public schools should send them to inner circle countries so that they can develop their productive, communicative, strategic and pragmatic competence and skills. Unless these productive skills are improved and the number of the students is reduced, it is almost impossible to address learners in Turkey in a realistic manner [41].

Another serious problem that the participants $(n=15)$ mentioned was that the economic level was low. They said that there was a strong relationship between economic development and learning a foreign language. If the economic problem could be solved, they said that students could perform better in the classroom settings. The students' low economic status affects their learning negatively. They $(n=14)$ also emphasized that even if technology was available in classroom environment and the learners followed social media, American movies, series and other internet-related tools, they were unable to speak English effectively because the whole teaching in the education system Turkey was reduced to only exams, which entailed the use of grammar-translation method. This system also affected the participants negatively [42].

In line with the problems mentioned above, it can be said that undeveloped economy, exam anxiety, the high number of the students in the classrooms, non-participatory political system in English education, absence of productive skills in the participants, the lack of critical thinking and critical pedagogy at macro and micro level, lack of oral skills, dominance of grammar translation method, rigidity of syllabus and curriculum, attitudes of the administrators and parents together affected English language teaching and learning in Turkey negatively. In addition, concrete solutions and recommendations by English language departments and Ministry of Education have hardly been addressed and brought. Therefore, the participants $(n=14)$ insistently emphasized that realistic and participatory approaches should be adopted, developed and reinforced. All of them $(n=14)$ said that they should be involved in the process of determining syllabus and curriculum as well as assessment. Figure 1 describes the themes from the interview.

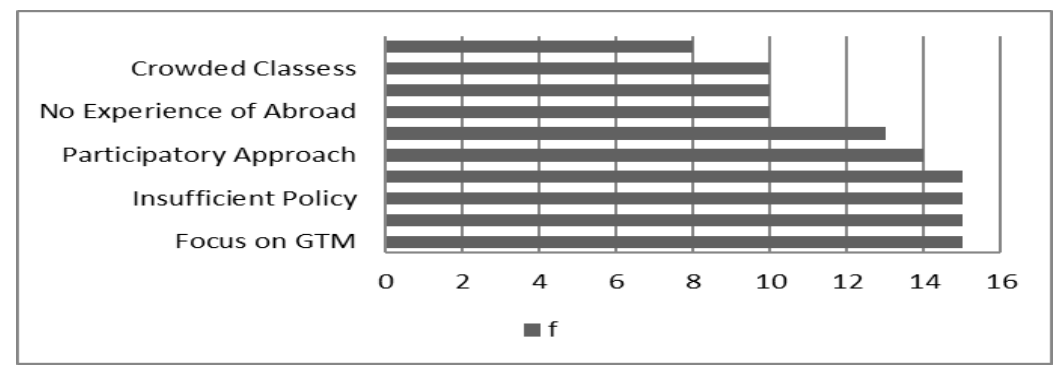

Figure 1. Themes from the remarks of the informants

\section{CONCLUSION}

The overall results of the study show that grammar-translation method is dominant and widely used in Turkey. Therefore, insignificant progress has been made in English teaching and learning. The exams in Turkey should leave out receptive-skill based question types. Instead, communicative-based questions should be prepared and designed to motivate learners to use English effectively and efficiently. In addition, English language teaching departments should adopt a more critical approach towards this system. Unless realistic approaches are developed, it is unlikely to help learners use English productively. Thus, productive skills should be adopted and developed so that learners can communicate effectively. Both teachers and learners should be involved in preparation of curricula and syllabus as well as tasks. The tenets of Common European Framework should be followed. Although in principle Turkey is supposed to conform to these tenets, it is hard to see the applications of Common European Framework. The failure of English language teaching and learning system can be attributed to the types and nature of exams as well as the use of grammar translation method. 


\section{REFERENCES}

[1] A. Mazrul, The political sociology of english language: An African perspective, Walter de Gruyter GmbH \& Co KG, 2019

[2] R. Sparks and L. Ganschow, "Aptitude for learning a foreign language," Annual Review of Applied Linguistics, vol. 21, pp. 90-111, 2001

[3] N. N. Ekhlas and N. Shangarffam, "The relationship between determinant factors of self-regulation strategies and main language skills and overall proficiency," Procedia-Social and Behavioral Sciences, vol. 70, pp. 137-147, 2013.

[4] C. A. Karademir and S. Gorgoz, "English teachers' problems encountered in teaching four basic language skills," International Education Studies, vol. 12, no. 4, pp. 118-127, 2019.

[5] N. Akhmadjanovna, M. H. Abdukhalilovna, and M. B. Habibullaevna, "Integrating language skills into the process of the English language teaching," Вестник науки и образования, vol. 73, pp. 19-22, 2019.

[6] Z. Dörnyei, "Motivation in second and foreign language learning," Language teaching, vol. 31, no. 3, pp. 117-135, 1998.

[7] D. Cetindamar, V. K. Gupta, E. E. Karadeniz, and N. Egrican, "What the numbers tell: The impact of human, family and financial capital on women and men's entry into entrepreneurship in Turkey," Entrepreneurship \& Regional Development, vol. 24, no. 1-2, pp. 29-51, 2012.

[8] A. Kilınç, H. M. Watt, and P. W. Richardson, "Factors influencing teaching choice in Turkey," Asia-Pacific Journal of Teacher Education, vol. 40, no. 3, pp. 199-226, 2012.

[9] S. Kurt, "Creating technology-enriched classrooms: Implementational challenges in Turkish education," Learning, Media and Technology, vol. 39, no. 1, pp. 90-106, 2014.

[10] MONE, "Ingilizce dersi ogretim programi (Ilkokul ve ortaokul 2, 3, 4, 5, 6, 7 ve 8. Siniflar) [English teaching program (Primary and Secondary School 2, 3, 4, 5, 6, 7 and 8th grades)]," Ankara: Ministry of National Education, 2018.

[11] P. Kaplan, "Milli eğitim bakanı ömer dinçer: 10 yılda how old are you dedirtemedik!" Haber Turk, 2011. [Online]. Available: https://www.haberturk.com/polemik/haber/664571-10-yilda-how-old-are-you-dedirtemedik. Accessed 10 Jan 2019

[12] N. Spaull, "Who makes it into PISA? Understanding the impact of PISA sample eligibility using Turkey as a case study (PISA 2003-PISA 2012)," Assessment in Education: Principles, Policy \& Practice, vol. 26, no. 4, pp. 397-421, 2019.

[13] Y. Balc1, "Some critical issues in innovation and economic development: Lessons from the recent Turkish experience," Procedia Computer Science, vol. 158, pp. 609-624, 2019.

[14] S. Ariogul, D. C. Unal, and I. Onursal, "Foreign language learners' beliefs about language learning: A study on Turkish university students," Procedia-Social and Behavioral Sciences, vol. 1, no. 1, pp. 1500-1506, 2009.

[15] F. Karahan, "Language attitudes of Turkish students towards the English language and its use in Turkish context," Cankaya University Journal of arts and sciences, vol. 1, no. 7, pp. 73-87, 2007.

[16] A. Coikun, "Causes of the "I Can Understand English but I Can't Speak" Syndrome in Turkey," Journal on English Language Teaching, vol. 6, no. 3, pp. 1-12, 2016.

[17] G. Öztürk and N. Gürbüz, "Speaking anxiety among Turkish EFL learners: The case at a state university," Dil ve Dilbilimi Çalışmaları Dergisi, vol. 10, no. 1, pp. 1-17, 2014.

[18] Z. Kiziltepe, "Attitudes and motivation of Turkish EFL students towards second language learning," ITLInternational Journal of Applied Linguistics, vol. 129, no. 1, pp. 141-168, 2000.

[19] M. Şenel, "Suggestions for beautifying the pronunciation of EFL learners in Turkey," Dil ve Dilbilimi Çallşmaları Dergisi, vol. 2, no. 1, pp. 111-125, 2006.

[20] M. Murphy, "The politics of adult education: state, economy and civil society," International Journal of Lifelong Education, vol. 20, no. 5, pp. 345-360, 2001.

[21] A. Kraak, "The education-economy relationship in South Africa, 2001-2005," Human resources development review, vol. 28, pp. 1-25, 2008.

[22] H. Hendarmin and M. Kartika, "The relationship between human capital and the regional economy productivity," JEJAK: Jurnal Ekonomi dan Kebijakan, vol. 12, no. 1, pp. 138-152, 2019.

[23] W. Gao, X. Ding, R. Chen, and Y. W. Min, "An empirical study of the role of higher education in building a green economy," Sustainability, vol. 11, no. 23, pp. 6823, 2019.

[24] E. Ataç, "Modeling educational inequalities: class, academic achievement, and regional differences in Turkey," Education and Urban Society, vol. 51, no. 5, pp. 659-692, 2019.

[25] A. D. Ayaz, S. Ozkardas, and T. Ozturan, "Challenges of English language teaching in high schools in turkey and possible suggestions to overcome them," Eurasian Journal of Applied Linguistics, vol. 5, no. 1, pp. 41-55, 2019.

[26] E. Kara, A. Ayaz, A. Demr, and T. Dündar, "Challenges in EFL speaking classes in Turkish context," European Journal of Language and Literature, vol. 3, no. 2, pp. 66-74, 2017.

[27] E. Solak and A. Bayar, "Current challenges in English language learning in Turkish efl context," Online Submission, vol. 2, no. 1, pp. 106-115, 2015.

[28] J, Richardson, "The concepts and methods of phenomenographic research," Review of educational research, vol. 69 , no. 1 , pp. 53-82, 1999.

[29] F. J. Murillo and N. Hidalgo, "Fair student assessment: A phenomenographic study on teachers' conceptions," Studies in Educational Evaluation, vol. 65, pp. 100860, 2020.

[30] Y. H. Tan and S. C. Tan, "Designing the phenomenographic study and constituting the outcome spaces," Conceptions of Knowledge Creation, Knowledge and Knowing, Springer, 2020. 
[31] J. Nilsson, M. Röing, J. Malmros, and J. Winterling, "Ways of understanding the ability to have children among young adult survivors of childhood cancer-A phenomenographic study," European Journal of Oncology Nursing, vol. 44, pp. 101710, 2020.

[32] D, Li, "It's always more difficult than you plan and imagine: Teachers' perceived difficulties in introducing the communicative approach in South Korea," TESOL quarterly, vol. 32, no. 4, pp. 677-703, 1988.

[33] H. M. Assalahi, "Why Is the Grammar-translation Method Still Alive in the Arab World? Teachers' Beliefs and Its implications for EFL Teacher Education," Theory \& Practice in Language Studies, vol. 3, no. 4, 2013.

[34] K. Sato and R. C. Kleinsasser, "Beliefs, practices, and interactions of teachers in a Japanese high school English department," Teaching and Teacher Education, vol. 20, no. 8, pp. 797-816, 2004.

[35] J. Thomas, "Cross-cultural pragmatic failure," Applied linguistics, vol. 4, no. 2, pp. 91-112, 1983.

[36] T. Paribakht, "Strategic competence and language proficiency," Applied linguistics, vol. 6, no. 2, pp. 132-146, 1985.

[37] S. J. Savignon, "Communicative language teaching: State of the art," TESOL quarterly, vol. 25, no. 2, pp. 261- 278, 1991

[38] M. C. Ho, "Culture studies and motivation in foreign and second language learning in Taiwan," Language Culture and Curriculum, vol. 11, no. 2, pp. 165-182, 1998.

[39] A. U. Chamot, "Issues in language learning strategy research and teaching," Electronic journal of foreign language teaching, vol. 1, no. 1, pp. 14-26, 2004.

[40] P. Handayani and S. S. Brodjonegoro, "Strengthening vocational character for polytechnic education which has non-production-based curriculum," REiD (Research and Evaluation in Education), vol. 1, no. 1, pp. 84-99, 2015.

[41] M. H. M. I. Hamid, M. Masrom, and K. R. Salim, "Review of learning models for production based education training in technical education," International Conference on Teaching and Learning in Computing and Engineering, pp. 206-211, 2014.

[42] G. J. Palardy, "High school socioeconomic segregation and student attainment," American Educational Research Journal, vol. 50, no. 4, pp. 714-754, 2013. 